\title{
A Look inside the Listeria monocytogenes Biofilms Extracellular Matrix
}

\author{
Angelo Colagiorgi, Pierluigi Di Ciccio *, Emanuela Zanardi, Sergio Ghidini and Adriana Ianieri \\ Department of Food Science, University of Parma, Via del Taglio 10, Parma 43126, Italy; \\ angelo.colagiorgi@studenti.unipr.it (A.C.); emanuela.zanardi@unipr.it (E.Z.); \\ sergio.ghidini@unipr.it (S.G.); adriana.ianieri@unipr.it (A.I.) \\ * Correspondence: pierluigialdo.diciccio@nemo.unipr.it; Tel.: +39-521-902-754
}

Academic Editor: Rikke Louise Meyer

Received: 31 March 2016; Accepted: 23 June 2016; Published: 5 July 2016

\begin{abstract}
Listeria monocytogenes is a foodborne pathogen able to persist in food industry and is responsible for a severe illness called listeriosis. The ability of L. monocytogenes to persist in environments is due to its capacity to form biofilms that are a sessile community of microorganisms embedded in a self-produced matrix of extracellular polymeric substances (EPS's). In this review, we summarized recent efforts performed in order to better characterize the polymeric substances that compose the extracellular matrix (ECM) of L. monocytogenes biofilms. EPS extraction and analysis led to the identification of polysaccharides, proteins, extracellular DNA, and other molecules within the listerial ECM. All this knowledge will be useful for increasing food protection, suggesting effective strategies for the minimization of persistence of L. monocytogenes in food industry environments.
\end{abstract}

Keywords: Listeria monocytogenes; listeriosis; extracellular polymeric substances (EPS's); biofilm; extracellular matrix; foodborne pathogens; food poisoning

\section{Introduction}

Listeria monocytogenes is an ubiquitous bacterium isolated from soil, water, wastewater, animals, humans, and raw or processed food [1]. It is a Gram-positive, facultative anaerobe, non-spore-forming, foodborne pathogen. L. monocytogenes is able to grow and survive in different environmental conditions due to its tolerance to low temperatures $\left(4^{\circ} \mathrm{C}-10^{\circ} \mathrm{C}\right)$, high $\mathrm{pH}$, and high salt concentrations [2], and the presence of polar flagella confers to such a microorganism a tumbling motility at room temperature [3].

L. monocytogenes is the etiological agent of a severe infection called listeriosis [4]. Although the disease is rare, listeriosis is an important public health problem because it is associated with high hospitalization and mortality rates. According to European Food Security Authority (EFSA), 1300 cases of listeriosis occur annually in the European Union (EU), whereas the Centers for Disease Control and Prevention (CDC) estimates that approximately 1600 cases occur every year in the United States of America (USA) [5-9], with a statistically significant increasing trend of listeriosis in the 2008-2014 period in the EU $[10,11]$ (Figure 1).

Elderly, pregnant women, newborns, and adults with weakened immune systems are the most affected by the disease, and septicemia, meningitis, miscarriage, and stillbirth are common clinical presentations [12-14], although people without these risk factors can also be affected [15,16].

The principal route of transmission is the consumption of contaminated food due to the ability of L. monocytogenes to survive and grow in acidic or salty conditions and to replicate at low temperatures $[17,18]$, and to colonize food processing environments, including equipment used in food processing operations [19], representing a serious concern for human health [20]. L. monocytogenes attach to a variety of surfaces, including stainless steel, polystyrene, and glass [21-23], and are able to form biofilms. Microbial cells in biofilms are embedded in a self-produced matrix of extracellular 
material, composed by a conglomeration of different types of biopolymers known as extracellular polymeric substances (EPS's) [24]. EPS's form the scaffold for a three-dimensional structure of the biofilm and are responsible for the adhesion to surfaces and cohesion in the biofilm [25]. Several features of a biofilm may vary depending on the production, the quantity, and the characteristics of the individual components of EPS's, such as cohesion, charge, concentration, and nature of molecules [26].

(a)

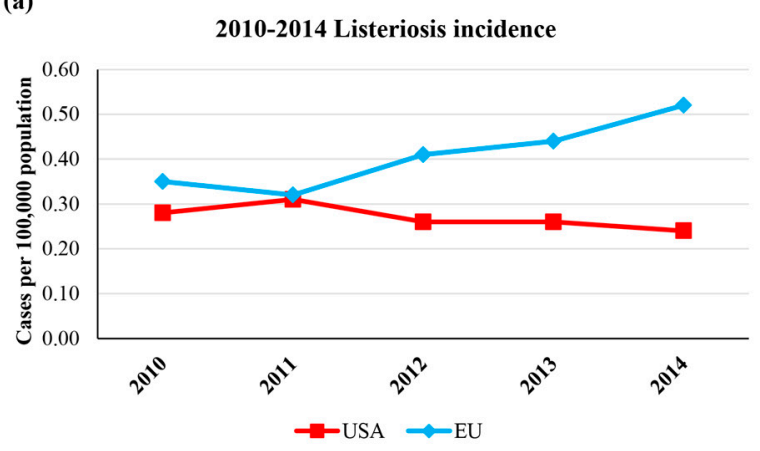

(b)

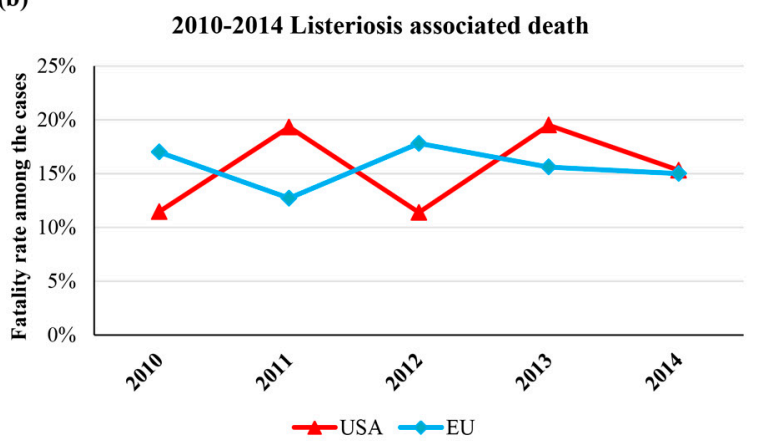

Figure 1. Listeriosis incidence and associated death in the USA and the EU from 2010 to 2014. Panel (a) shows the number of cases of listeriosis per 100,000 population; in panel (b), the percentage of listeriosis associated death among the confirmed illness cases are reported.

The biofilm matrix can account for more than $90 \%$ of the dry mass of a biofilm [25]. Polysaccharides, proteins, and DNA compose the extracellular matrix of many biofilms [25]. These molecules are involved in adhesion to surface, cohesion within the biofilm, and aggregation of bacterial cells. Furthermore, retention of water (preventing desiccation), protection against antimicrobial agents (acting as protective barrier), sorption of organic and inorganic compounds (acting as a reservoir of energy), and enzymatic activity are some of the activities performed by EPS's in bacterial biofilms [25].

Many studies have been carried out aiming to better understand the complexity of the biofilm extracellular material in both Gram-positive and -negative microorganisms. Several molecules have been identified and characterized, i.e., different exopolysaccharides, proteins and extracellular DNA (eDNA), in the biofilm matrix of Staphylococcus aureus, Escherichia coli, Pseudomonas aeruginosa, Vibrio cholerae, and others [27-30]. However, as for L. monocytogenes, information is so far not abundant. In this review, we summarize the status of experimental efforts aimed at characterizing ECM of L. monocytogenes biofilms.

\section{Listeria monocytogenes and Biofilms}

L. monocytogenes is able to persist in food environments, representing an important source of contamination that can lead to food spoilage or transmission of disease [22]. Biofilm formation is important for the survival of L. monocytogenes in the food industry, e.g., it was observed that biofilms formed by strains that persist in the industry are thicker than those formed by isolates found only sporadically [31]. Furthermore, listerial cells embedded in biofilms are different in structure and physiology from the planktonic ones, e.g., adherent cells change their shape from rod to coccoid as the population aged, grew more slowly [32], are more resistant to antibiotics and sanitizers, and harder to remove and destroy $[33,34]$. The ability to form biofilms has been reported to be different among different isolates, but it was not possible to establish a clear correlation with serovars or lineages [35,36]. Many authors have agreed that L. monocytogenes biofilms are strongly influenced by temperature [22,37,38], strain [35,39,40], incubation time [41], medium [37,38], and the nature of the adhesion surface [42,43]. Moreover, the fatty acids profile of biofilm forming listerial cells was analyzed, and an increase in the amount of certain fatty acids (iso- $C_{14: 0}$, anteiso- $C_{15: 0}$, and iso- $C_{16: 0}$ ) with an increase in biofilm forming ability of the isolates was observed, possibly indicating a relationship between total fatty acid composition of the biofilm and the biofilm-forming ability of a strain [44-46]. 
A variety of structures of L. monocytogenes biofilms have been described, including a monolayer of adherent cells, flat unstructured multilayers, and a knitted-chain network, depending on the strains and experimental setup used [35,39,47-50]. Recently, Guilbaud et al. [51], using three-dimensional reconstruction of confocal laser scanning microscopy (CLSM) images acquired by Leica SP2 AOBS Confocal Laser Scanning Microscope (Leica-Microsystems, Wetzlar, Germany), observed L. monocytogenes intraspecies diversity in the ability to form biofilm. They analyzed biofilm architecture formed by 96 isolates and observed that the majority of listerial strains formed honeycomb-like structures consisting of layers of cohesive cells, heterogeneously distributed, decorated with hollow voids with diameters ranging from 5 to $50 \mu \mathrm{m}$. Within the hollow voids, swimming bacteria were observed, whereas an inner compact matrix was lacking. Biofilm staining with propidium iodide revealed pockets formed by dead cells and eDNA. This spatial organization is common to various microorganisms, since it has previously been described in staphylococcal species [28,52] and in Enterococcus faecalis [53], and has been reported for L. monocytogenes by Marsh et al. [49].

In the end, it appears that a multitude of parameters influence the biofilm structure of L. monocytogenes, such as the strain, the surface, and other environmental conditions, such as $\mathrm{pH}$, temperature, and medium [47].

\section{The L. monocytogenes Biofilm Extracellular Matrix}

Since the ability of L. monocytogenes to produce EPS's has been controversial for a long time, several studies have been done in order to demonstrate the extracellular matrix production by various listerial strains. Staining with ruthenium red [35,54] and Congo red [55,56], fluorescein-conjugated lectin binding [57], fluorescent dye-conjugated antibody binding [58], phenolic sulfuric acid analysis [59], and fibril or matrix analysis via scanning electron microscope (SEM) $[35,54,57,59]$ have been performed. Extracellular matrix composition has been examined mainly by nuclear magnetic resonance (NMR, Bruker, Billerica, Massachusetts, MA, USA) [60,61], gas chromatography-mass spectrometry (GC-MS, Thermo Scientific, Waltham, Massachusetts, MA, USA) [60], and CLSM [51,62] analyses. Here, we report the current knowledge about Listeria biofilm extracellular matrix, as summarized in Table 1.

\subsection{Exopolysaccharides and Teichoic Acids}

Exopolysaccharides are the major components of the extracellular matrix in many microorganisms $[63,64]$. In mucoid strains of Pseudomonas aeruginosa, alginate is the principal component of EPS's [65], whereas poly-N-acetyl glucosamine (PNAG) and teichoic acids (TAs) were found in the $S$. aureus biofilm matrix [66]. In the early 2000s, Borucki et al. [35] reported the presence of carbohydrates in all L. monocytogenes strains tested in their work, with the highest biofilm formers producing noticeably more polysaccharides [35]. Recent studies have deeply investigated the structure of the carbohydrate component of the L. monocytogenes extracellular matrix.

As reported recently, Alonso et al. [67] performed a transposon mutagenesis library screen using a Himar1 mariner transposon in order to investigate genetic elements involved in biofilm formation. The authors identified a total of 38 genetic loci involved in the biofilm formation process. In particular, they investigated further two of these loci, the D-alanylation pathway genes $d l t A B C D$ and the phosphate-sensing two-component system phoPR. The results, obtained by deletion of these loci, indicated a significant reduction in biofilm formation by the mutant strains compared with wild-type bacteria in a polyvinyl chloride (PVC) microtiter plate assay and by CLSM. The D-alanylation of lipoteichoic acids (LTAs) and the phosphate-sensing phoPR two-component system both appear to play critical roles for biofilm formation by L. monocytogenes. 
Table 1. Structural components of Listeria monocytogenes extracellular matrix. EPS's characterized so far and their role within biofilm matrix are listed here.

\begin{tabular}{|c|c|c|c|}
\hline EPS & Molecules & Features & References \\
\hline Polysaccharides & $\begin{array}{c}\text { poly- } \beta-(1,4)-N \text {-acetylmannosamine } \\
\text { (poly-NAM) } \\
\text { Teichoic Acids (WTA and LTA) }\end{array}$ & $\begin{array}{l}\text { - Teichoic acids are the major component of } \\
\text { listerial biofilm matrix } \\
-\quad d l t A B C D \text { mutants present a reduction in } \\
\text { biofilm forming ability } \\
-\quad \text { Biosynthesis of poly-NAM is activated by } \\
\text { high levels of c-di-GMP }\end{array}$ & $\begin{array}{l}{[60]} \\
{[67]} \\
{[61]}\end{array}$ \\
\hline Proteins & $\begin{array}{c}\text { InlA } \\
\text { BapL } \\
\text { PlcA } \\
\text { FlaA } \\
\text { PBP } \\
\text { ActA } \\
\text { Lmo2504 }\end{array}$ & $\begin{array}{l}\text { - Proteinase K treatment impairs biofilm } \\
\text { development, suggesting protein involvement in } \\
\text { initial attachment } \\
-\quad \text { Truncated proteins exhibited enhanced } \\
\text { biofilm forming ability } \\
-\quad \text { BapL can contribute to the attachment of } \\
\text { some L. monocytogenes strains } \\
\text { - Flagellar motility has controversial role in } \\
\text { biofilm formation }\end{array}$ & $\begin{array}{c}{[68,69]} \\
{[70]} \\
{[71]} \\
{[32,51,72,73]}\end{array}$ \\
\hline $\begin{array}{c}\text { Extracellular } \\
\text { DNA }\end{array}$ & & $\begin{array}{l}\text { - DNAseI treatment inhibited or delayed } \\
\text { initial attachment of bacteria to surfaces, } \\
\text { suggesting eDNA involvement in initial } \\
\text { attachment } \\
-\quad \text { Ensure structural integrity of biofilm in } \\
\text { cooperation with proteins and polysaccharides } \\
-\quad \text { Involved in Horizontal Gene Transfer } \\
-\quad \text { Serves as energy and nutrition source } \\
-\quad \text { eDNA is released by lysed bacteria }\end{array}$ & $\begin{array}{c}{[62,74,75]} \\
{[74]} \\
{[51]} \\
{[62,74]}\end{array}$ \\
\hline
\end{tabular}

NOTE: WTA: Wall Teichoic Acids; LTA: Lipoteichoic Acids; c-di-GMP: cyclic diguanosine monophosphate.

The importance of TAs within the L. monocytogenes biofilm matrix was confirmed by Brauge et al. [60]. GC-MS (Thermo Scientific, Waltham, Massachusetts, MA, USA) and ${ }^{13} \mathrm{C}$ - and ${ }^{1}$ H-NMR spectroscopy (Bruker, Billerica, Massachusetts, MA, USA) analyses of soluble carbohydrates extracted from a 48-h biofilm extracellular matrix and culture supernatant of six strains of L. monocytogenes led to the identification of TAs. Interestingly, such molecules were structurally identical to TAs isolated from the cell wall. Furthermore, a mutant strain encoding TAs lacking NAG glycosylation presented an extracellular carbohydrate fraction identical to the modified cell wall molecules. These findings suggest that extracellular and cell wall TAs may have the same origin, probably deriving from autolysis and the peeling of bacteria. Similar data were reported by Savdovskaya et al. [76] who compared extracellular and cell wall TA structures of the reference biofilm-positive strain S. epidermidis RP62A.

The extracellular TAs were the only carbohydrate polymers identified in the work of Brauge et al. [60], whereas Köseoğlu et al. [61] recently reported the presence of an insoluble cell-bound poly- $\beta-(1,4)-N$-acetylmannosamine decorated with terminal $\alpha-1,6$-linked galactose (ManNAc-Gal) identified in a constructed aggregate-forming mutant strain of EGD-e. These contrasting results may be explained considering that the native ManNAc-Gal is completely insoluble, so the liquid-state NMR analysis by Köseoğlu et al. [61] on the listerial EPS's was conducted after the $N$-deacetylation of such molecules. The biosynthesis of such EPS's, produced by the $p S S A-E$ operon, is activated by elevated levels of the second messenger c-di-GMP, as previously observed in proteobacteria [77]. This molecule was found to be involved in biofilm formation and regulation in several bacterial species, i.e., regulation of alginate [78] and the glucose rich matrix polysaccharide Pel [79] biosynthesis in P. aeruginosa, and cellulose synthesis in many proteobacteria [80-82]. The c-di-GMP signaling networks are likely very complex, as a large number of c-di-GMP signaling proteins has been predicted in many bacterial species, and it is not clear how several input signals are integrated by microorganisms to control bacterial behavior $[83,84]$. Generally, high levels of c-di-GMP are required for bacteria to become sessile. The c-di-GMP-induced ManNAc-Gal of L. monocytogenes was found to be responsible 
for various phenotypic traits, i.e., cell aggregation, reduced motility in semi-solid media, moderate decrease of invasiveness in mammalian cells, and a highly increased tolerance to disinfectants and dehydration, aiding bacteria to persist in the environment.

\subsection{Extracellular and Biofilm-Associated Surface Proteins}

The role of surface or extracellular proteins in the initial attachment of L. monocytogenes to a surface has been demonstrated in different studies [68,69,85]. In 2012, Combrouse et al. [59] firstly quantified the extracellular components of the L. monocytogenes biofilm and reported that extracellular proteins are the most abundant exopolymers within the listerial biofilm matrix. According to Longhi et al. [68], the protease treatment of listerial biofilm is able to impair biofilm development or to induce dispersal of the cells. Moreover, Nguyen et al. [69] recently observed the reduction of established biofilms to undetectable levels after treatment with proteinase $\mathrm{K}$. Treatment with proteinase $\mathrm{K}$ led to a noticeable increase in planktonic cell density. According to other findings, the protease inhibitor $\alpha 2-m a c r o g l o b u l i n$ severely impairs biofilm formation, suggesting that proteolytically processed proteins are more likely to be part of the L. monocytogenes biofilms [70]. All these results suggest that proteins within the biofilm matrix or on the cell surface are a key part of the EPS matrix. Nonetheless, there is a paucity of information about the characterization of the proteic components of the listerial matrix.

L. monocytogenes is able to encode more than 130 surface proteins that can confer to this bacterium the ability to survive in diverse environments [86,87]. Among these, Internalin A (InlA) is a cell-wall-bound protein and is one of the major components involved in the adhesion to and invasion of a host cell expressing a specific form of E-cadherin. Franciosa et al. [70] found that L. monocytogenes strains encoding a truncated non-functional form of the InlA protein exhibited significantly enhanced biofilm-forming ability compared with wild-type strains. Such a truncated molecule, fully released in the extracellular medium, was hypothesized to be part of the biofilm matrix.

Biofilm-associated protein (Bap) is a surface protein involved in biofilm formation in different bacterial species [88], such as S. aureus, Enterococcus faecalis, or the Gram-negative Salmonella enterica sv typhimurium [89-92]. The high-molecular-weight Bap-related proteins present a core domain of tandem repeats and are able to confer to bacteria the capacity to form a biofilm [88]. Concerning L. monocytogenes, Jordan et al. [71] reported the presence of a protein similar to Bap, presenting Bap-like structural features and thus designated BapL. Similar to some Bap-related proteins found in other species, such a molecule is required for cell attachment to abiotic surfaces, while on the contrary, it is not required for virulence [71]. BapL can contribute to the attachment of some L. monocytogenes strains, but its role in biofilm development has not been clearly established: Renier et al. [47], in fact, showed that some BapL-negative strains were able to adhere significantly better than BapL-positive strains, whereas the attachment ability of other strains was weakened.

Comparison of exoproteome of L. monocytogenes from biofilm and planktonic state by Lourenço et al. [73] led to the identification of proteins in higher abundance in the biofilm exoproteome. Phospholipase PlcA, flagellin (FlaA), a putative penicillin-binding protein (PBP), an actin assembly inducing protein (ActA), and a putative cell wall binding protein (Lmo2504) were among these identified proteins. Flagellin is a monomer that polymerizes to form the flagella. Different groups reported the importance of flagella during L. monocytogenes biofilm development [72,93], but their exact role in the process remains unclear because of conflicting results. It is well-known that L. monocytogenes has a temperature-dependent motility, since flagellin is expressed between 20 and $25^{\circ} \mathrm{C}$ [94]. According to Lourenço et al. [73] and Hefford et al. [57], the amount of flagellin within the proteome is higher in biofilms than in planktonic bacteria, although Trémoulet et al. [32] reported contrasting findings. Lemon et al. [72] found that flagellum-minus and paralyzed-flagellum mutants were defective in the step of initial attachment to surface and in subsequent biofilm formation. According to their findings, the importance of flagella in biofilm formation is related to their role in motility of cells, since the ability to form a biofilm of different flagella mutant strains was restored by supplying surface-directed motility exogenously via centrifugation. According to Zetzmann et al. [62], listerial flagella could have a role 
in biofilm formation under a static condition, whereas flagellar motility may have the opposite effect when bacteria are in a flow chamber. SEM observations by Guilbaud et al. [51] recently revealed the presence of extracellular fibrils in the L. monocytogenes biofilm honeycomb-like structures, putatively identified as flagella since they were absent in biofilm produced by non-motile or flagella mutant L. monocytogenes strains. Although biofilm formation was not prevented, the lack of such fibrils resulted in a flat and unstructured architecture of biofilm, suggesting a structural role in the three-dimensional architecture of listerial biofilms. It is still not clear whether either the flagella presence on its own or the flagellar motility are involved in biofilm formation and development; nonetheless, all findings suggest the importance of these structures during attachment to surface.

\subsection{Extracellular DNA}

Extracellular DNA is an important structural component of the EPS matrix of a wide range of Gram-positive and -negative bacteria [75], where it cooperates with proteins and polysaccharides ensuring structural integrity of the biofilm [95-99]. Concerning L. monocytogenes, Harmsen et al. [74] found the presence of DNA in stationary-phase cultures grown in a brain-heart-infusion (BHI) medium. They also showed that DNaseI treatment of the supernatant inhibited the initial attachment of bacteria to glass (in cultures diluted in PBS) and the delayed biofilm formation of bacteria grown in a minimal medium in polystyrene microtiter plates. Moreover, Zetzmann et al. [62] recently provided evidence that eDNA serves as a structural component of the EPS matrix of L. monocytogenes EGD-e, serotype $1 / 2 \mathrm{a}$, in a diluted BHI medium under both static and dynamic conditions, suggesting the targeting of this molecule for preventing or dispersing biofilm formation of these microorganisms.

Different studies on eDNA of L. monocytogenes biofilms have been done for a better understanding of the origin of the nucleic acids in the extracellular matrix $[62,74,75,100]$. It has been hypothesized that, under environmental conditions, eDNA released by lysed bacteria (or present in the environment) supports an initial attachment to surfaces. The lysis of bacteria cells already attached to the surface could be increased by hypotonic conditions, and the released DNA may have a double role in the biofilm: to constitute an anchoring site for dividing cells in microcolonies and to serve as a scavenger for further planktonic cells recruiting [62]. The hypothesis that eDNA can take origin from lysed cells was already supported by Harmsen et al., who demonstrated the chromosomal origin of eDNA by polymerase chain reaction (PCR) amplification [74].

Besides its structural role, eDNA serves also as an energy and nutrition source. In the case of L. monocytogenes, Guibaud et al. [51] observed the presence of DNA pockets in biofilms with honeycomb-like structures, hypothesizing that this phenomenon could provide nutrients for the starved surviving subpopulation. Furthermore, eDNA represents a repertoire of genes from which naturally competent bacteria can derive genetic information through horizontal gene transfer (HGT), a mechanism by which genetic information is passed from one bacterial genome to another [74].

\section{Conclusions and Perspectives}

L. monocytogenes is an important foodborne pathogen thanks to its ability to persist in the food industry by the formation of biofilms. Several efforts have been made in order to better understand L. monocytogenes biofilm composition. The extracellular matrix is the major component of the biofilms and the most difficult to study due to the presence of a large range of biopolymers that are difficult to analyze. For this reason, it has also been called "the dark matter of biofilm" [101].

The recent molecular and chemical studies focused on EPS matrix composition of L. monocytogenes have expanded the knowledge about biofilm structure of this pathogen. Several molecules have been characterized within the extracellular matrix, such as TAs, EPS's, surface-associated proteins, flagella, and eDNA (Figure 2). Different studies have contributed to determining the complexity and the function of these components during biofilm formation and development, from the initial adhesion to surface to the dispersal of cells to the planktonic state. However, more efforts and studies are required for discovering and improving our understanding of the molecules and mechanisms involved in this 
process. A deeper knowledge of listerial biofilm composition and formation process is pivotal for developing effective strategies aimed at minimizing L. monocytogenes persistence in the food industry and therefore new foodborne outbreaks involving this pathogen.

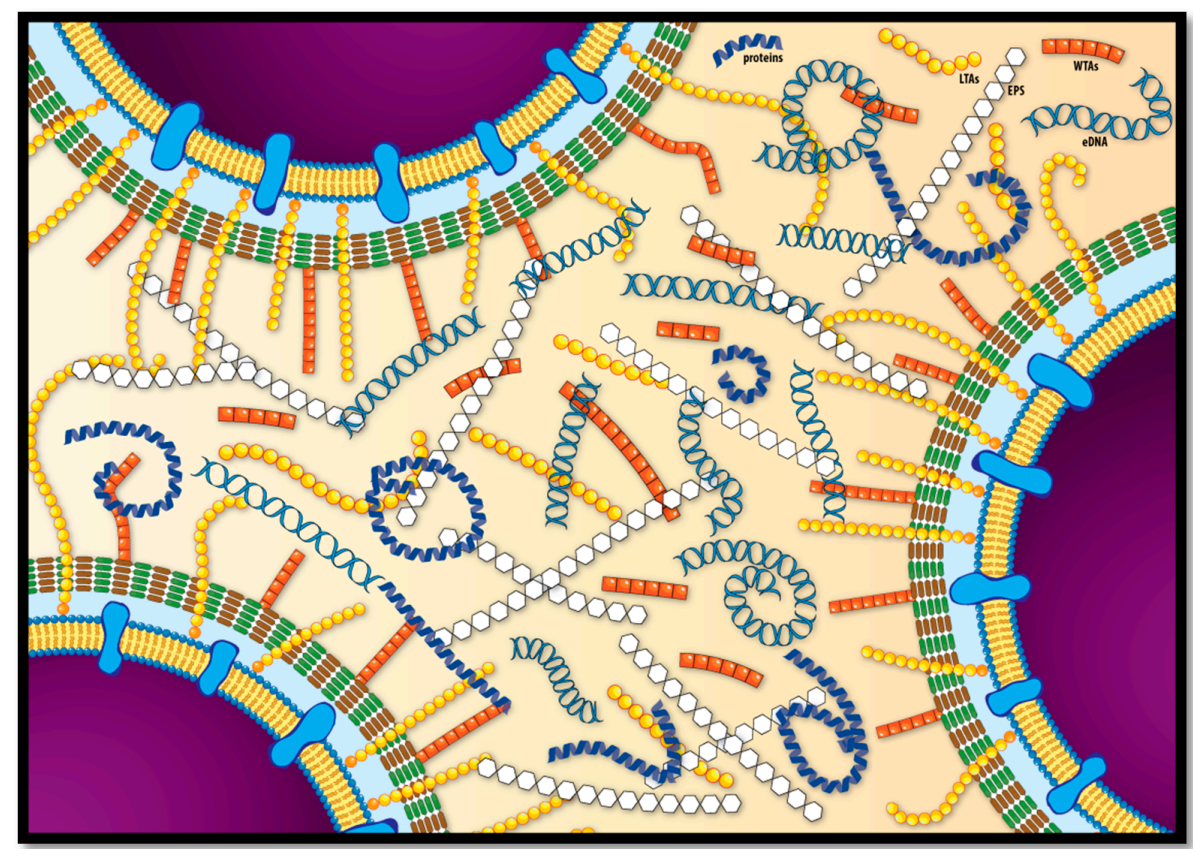

Figure 2. Schematic representation of listerial extracellular biofilm matrix. The major components (EPS's, WTAs, LTAs, proteins, and eDNA) are distributed heterogeneously within the matrix.

Acknowledgments: The following authors (Pierluigi Di Ciccio and Adriana Ianieri) are members of the EU COST Action FA1202 (CGA-FA1202): A European Network for Mitigating Bacterial Colonisation and Persistence on Foods and Food Processing Environments and acknowledge this action for facilitating collaborative networking that assisted with this study.

Author Contributions: Angelo Colagiorgi and Pierluigi Di Ciccio: participated in data collection and drafted the manuscript. Emanuela Zanardi, Sergio Ghidini, and Adriana Ianieri: critically revised the paper. All authors read and approved the final manuscript.

Conflicts of Interest: The authors declare no conflict of interest.

\section{Abbreviations}

The following abbreviations are used in this manuscript:

$\begin{array}{ll}\text { BHI } & \text { brain heart infusion } \\ \text { CDC } & \text { Centers for Disease Control and Prevention } \\ \text { c-di-GMP } & \text { Cylic diguanosine monophosphate } \\ \text { CLSM } & \text { confocal laser scanning microscopy } \\ \text { ECM } & \text { extracellular matrix } \\ \text { EFSA } & \text { European Food Safety Authority } \\ \text { EPS's } & \text { extracellular polymeric substances } \\ \text { GS-MS } & \text { gas chromatography-mass spectrometry } \\ \text { HGT } & \text { horizontal gene transfer } \\ \text { L. monocytogenes } & \text { Listeria monocytogenes } \\ \text { LTAs } & \text { lipoteichoic acids } \\ \text { NMR } & \text { nuclear magnetic resonance } \\ \text { PVC } & \text { polyvinyl chloride } \\ \text { SEM } & \text { scanning electron microscopy } \\ \text { TAs } & \text { teichoic acids } \\ \text { WTAs } & \text { wall teichoic acids }\end{array}$




\section{References}

1. Ivanek, R.; Gröhn, Y.T.; Wiedmann, M. Listeria monocytogenes in multiple habitats and host populations: Review of available data for mathematical modeling. Foodborne Pathog. Dis. 2006, 3, 319-336. [CrossRef] [PubMed]

2. Rocourt, J.; Cossart, P. Listeria monocytogenes . In Food Microbiology_Fundamentals and Frontiers; Doyle, M.P., Buechat, L.R., Montville, T.J., Eds.; American Society for Microbiology (ASM) Press: Washington, DC, USA, 1997; pp. 337-352.

3. Schirm, M.; Kalmokoff, M.; Aubry, A.; Thibault, P.; Sandoz, M.; Logan, S.M. Flagellin from Listeria monocytogenes is glycosylated with beta-O-linked $\mathrm{N}$-acetylglucosamine. J. Bacteriol. 2004, 186, 6721-6727. [CrossRef] [PubMed]

4. Schlech, W.F., 3rd; Lavigne, P.M.; Bortolussi, R.A.; Allen, A.C.; Haldane, E.V.; Wort, A.J.; Hightower, A.W.; Johnson, S.E.; King, S.H.; Nicholls, E.S.; et al. Epidemic listeriosis-Evidence for transmission by food. N. Engl. J. Med. 1983, 308, 203-206. [CrossRef] [PubMed]

5. Scallan, E.; Hoekstra, R.M.; Angulo, F.J.; Tauxe, R.V.; Widdowson, M.A.; Roy, S.L.; Jones, J.L.; Griffin, P.M. Foodborne illness acquired in the united states-major pathogens. Emerg. Infect. Dis. 2011, 17, 7-15. [CrossRef] [PubMed]

6. ECDC. Food-and Waterborne Diseases and Zoonoses; ECDC: Stockholm, Sweden, 2014.

7. EFSA. The european union summary report on trends and sources of zoonoses, zoonotic agents and food-borne outbreaks in 2013. EFSA J. 2015, 13, 165.

8. CDC. Incidence and trends of infection with pathogens transmitted commonly through food-foodborne diseases active surveillance network, 10 US sites, 2006-2013. Morb. Mortal. Wkly. Rep. 2014, 63, 328-332.

9. De Noordhout, C.M.; Devleesschauwer, B.; Angulo, F.J.; Verbeke, G.; Haagsma, J.; Kirk, M.; Havelaar, A.; Speybroeck, N. The global burden of listeriosis: A systematic review and meta-analysis. Lancet Infect. Dis. 2014, 14, 1073-1082. [CrossRef]

10. EFSA. The european union summary report on trends and sources of zoonoses, zoonotic agents and food-borne outbreaks in 2014. EFSA J. 2015, 13, 191.

11. CDC. Foodborne Diseases Active Surveillance Network (Foodnet): Foodnet Surveillance Report for 2012 (Final Report); U.S. Department of Health and Human Services, CDC: Atlanta, GA, USA, 2014.

12. Silk, B.J.; Date, K.A.; Jackson, K.A.; Pouillot, R.; Holt, K.G.; Graves, L.M.; Ong, K.L.; Hurd, S.; Meyer, R.; Marcus, R.; et al. Invasive listeriosis in the foodborne diseases active surveillance network (foodnet), 2004-2009: Further targeted prevention needed for higher-risk groups. Clin. Infect. Dis. Off. Publ. Infect. Dis. Soc. Am. 2012, 54 (Suppl. 5), S396-S404. [CrossRef] [PubMed]

13. Painter, J.; Slutsker, L. Listeriosis in humans. In Listeria, Listeriosis and Food Safety, 3rd ed.; CRC press: Boca Raton, FL, USA, 2007; pp. 85-109.

14. Jackson, K.A.; Iwamoto, M.; Swerdlow, D. Pregnancy-associated listeriosis. Epidemiol. Infect. 2010, 138, 1503-1509. [CrossRef] [PubMed]

15. Riedo, F.X.; Pinner, R.W.; Tosca, M.L.; Cartter, M.L.; Graves, L.M.; Reeves, M.W.; Weaver, R.E.; Plikaytis, B.D.; Broome, C.V. A point-source foodborne listeriosis outbreak: Documented incubation period and possible mild illness. J. Infect. Dis. 1994, 170, 693-696. [CrossRef] [PubMed]

16. Dalton, C.B.; Austin, C.C.; Sobel, J.; Hayes, P.S.; Bibb, W.F.; Graves, L.M.; Swaminathan, B.; Proctor, M.E.; Griffin, P.M. An outbreak of gastroenteritis and fever due to Listeria monocytogenes in milk. N. Engl. J. Med. 1997, 336, 100-105. [CrossRef] [PubMed]

17. Jacobson, L. Listeriosis. Pediatr. Rev. Am. Acad. Pediatr. 2008, 29, 410-411. [CrossRef] [PubMed]

18. Allerberger, F. Listeria. In Foodborne Diseases; Simjee, S., Ed.; Humana Press: Totowa, NJ, USA, 2007; pp. 27-39.

19. Farber, J.M.; Peterkin, P.I. Listeria monocytogenes, a food-borne pathogen. Microbiol. Rev. 1991, 55, 476-511. [PubMed]

20. Vazquez-Boland, J.A.; Kuhn, M.; Berche, P.; Chakraborty, T.; Dominguez-Bernal, G.; Goebel, W.; Gonzalez-Zorn, B.; Wehland, J.; Kreft, J. Listeria pathogenesis and molecular virulence determinants. Clin. Microbiol. Rev. 2001, 14, 584-640. [CrossRef] [PubMed]

21. Blackman, I.C.; Frank, J.F. Growth of Listeria monocytogenes as a biofilm on various food-processing surfaces. J. Food Prot. 1996, 59, 827-831. 
22. Di Bonaventura, G.; Piccolomini, R.; Paludi, D.; D’Orio, V.; Vergara, A.; Conter, M.; Ianieri, A. Influence of temperature on biofilm formation by Listeria monocytogenes on various food-contact surfaces: Relationship with motility and cell surface hydrophobicity. J. Appl. Microbiol. 2008, 104, 1552-1561. [CrossRef] [PubMed]

23. Mafu, A.A.; Roy, D.; Goulet, J.; Savoie, L. Characterization of physicochemical forces involved in adhesion of Listeria monocytogenes to surfaces. Appl. Environ. Microbiol. 1991, 57, 1969-1973. [PubMed]

24. Donlan, R.M.; Costerton, J.W. Biofilms: Survival mechanisms of clinically relevant microorganisms. Clin. Microbiol. Rev. 2002, 15, 167-193. [PubMed]

25. Flemming, H.C.; Wingender, J. The biofilm matrix. Nat. Rev. Microbiol. 2010, 8, 623-633. [CrossRef] [PubMed]

26. Sutherland, I.W. The biofilm matrix-An immobilized but dynamic microbial environment. TIM 2001, 9 , 222-227. [CrossRef]

27. Ma, L.; Wang, J.; Wang, S.; Anderson, E.M.; Lam, J.S.; Parsek, M.R.; Wozniak, D.J. Synthesis of multiple Pseudomonas aeruginosa biofilm matrix exopolysaccharides is post-transcriptionally regulated. Environ. Microbiol. 2012, 14, 1995-2005. [CrossRef] [PubMed]

28. Schaudinn, C.; Stoodley, P.; Kainović, A.; O’Keeffe, T.; Costerton, B.; Robinson, D.; Baum, M.; Ehrlich, G.; Webster, P. Bacterial biofilms, other structures seen as mainstream concepts. Microbe 2007, 2, 231-237. [CrossRef]

29. Otto, M. Staphylococcal biofilms. Curr. Top. Microbiol. Immunol. 2008, 322, 207-228. [PubMed]

30. Berk, V.; Fong, J.C.N.; Dempsey, G.T.; Develioglu, O.N.; Zhuang, X.; Liphardt, J.; Yildiz, F.H.; Chu, S. Molecular architecture and assembly principles of Vibrio cholerae biofilms. Science 2012, 337, 236-239. [CrossRef] [PubMed]

31. Lunden, J.M.; Miettinen, M.K.; Autio, T.J.; Korkeala, H.J. Persistent Listeria monocytogenes strains show enhanced adherence to food contact surface after short contact times. J. Food Prot. 2000, 63, 1204-1207. [PubMed]

32. Trémoulet, F.; Duché, O.; Namane, A.; Martinie, B.; Labadie, J.C. Comparison of protein patterns of Listeria monocytogenes grown in biofilm or in planktonic mode by proteomic analysis. FEMS Microbiol. Lett. 2002, 210, 25-31. [CrossRef]

33. Hall-Stoodley, L.; Costerton, J.W.; Stoodley, P. Bacterial biofilms: From the natural environment to infectious diseases. Nat. Rev. Microbiol. 2004, 2, 95-108. [CrossRef] [PubMed]

34. Carpentier, B.; Cerf, O. Review-Persistence of Listeria monocytogenes in food industry equipment and premises. Int. J. Food Microbiol. 2011, 145, 1-8. [CrossRef] [PubMed]

35. Borucki, M.K.; Peppin, J.D.; White, D.; Loge, F.; Call, D.R. Variation in biofilm formation among strains of Listeria monocytogenes. Appl. Environ. Microbiol. 2003, 69, 7336-7342. [CrossRef] [PubMed]

36. Djordjevic, D.; Wiedmann, M.; McLandsborough, L.A. Microtiter plate assay for assessment of Listeria monocytogenes biofilm formation. Appl. Environ. Microbiol. 2002, 68, 2950-2958. [CrossRef] [PubMed]

37. Mai, T.L.; Conner, D.E. Effect of temperature and growth media on the attachment of Listeria monocytogenes to stainless steel. Int. J. Food Microbiol. 2007, 120, 282-286. [CrossRef] [PubMed]

38. Moltz, A.G.; Martin, S.E. Formation of biofilms by Listeria monocytogenes under various growth conditions. J. Food Prot. 2005, 68, 92-97. [PubMed]

39. Chae, M.S.; Schraft, H. Comparative evaluation of adhesion and biofilm formation of different Listeria monocytogenes strains. Int. J. Food Microbiol. 2000, 62, 103-111. [CrossRef]

40. Tresse, O.; Shannon, K.; Pinon, A.; Malle, P.; Vialette, M.; Midelet-Bourdin, G. Variable adhesion of Listeria monocytogenes isolates from food-processing facilities and clinical cases to inert surfaces. J. Food Prot. 2007, 70, 1569-1578. [PubMed]

41. Harvey, J.; Keenan, K.P.; Gilmour, A. Assessing biofilm formation by Listeria monocytogenes strains. Food Microbiol. 2007, 24, 380-392. [CrossRef] [PubMed]

42. Midelet, G.; Carpentier, B. Impact of cleaning and disinfection agents on biofilm structure and on microbial transfer to a solid model food. J. Appl. Microbiol. 2004, 97, 262-270. [CrossRef] [PubMed]

43. Midelet, G.; Kobilinsky, A.; Carpentier, B. Construction and analysis of fractional multifactorial designs to study attachment strength and transfer of Listeria monocytogenes from pure or mixed biofilms after contact with a solid model food. Appl. Environ. Microbiol. 2006, 72, 2313-2321. [CrossRef] [PubMed]

44. Chao, J.; Wolfaardt, G.M.; Arts, M.T. Characterization of Pseudomonas aeruginosa fatty acid profiles in biofilms and batch planktonic cultures. Can. J. Microbiol. 2010, 56, 1028-1039. [CrossRef] [PubMed] 
45. Chihib, N.E.; da Silva, M.R.; Delattre, G.; Laroche, M.; Federighi, M. Different cellular fatty acid pattern behaviours of two strains of Listeria monocytogenes Scott A and CNL 895807 under different temperature and salinity conditions. FEMS Microbiol. Lett. 2003, 218, 155-160. [CrossRef] [PubMed]

46. Perez, L.J.; Ng, W.L.; Marano, P.; Brook, K.; Bassler, B.L.; Semmelhack, M.F. Role of the CAI-1 fatty acid tail in the Vibrio cholerae quorum sensing response. J. Med. Chem. 2012, 55, 9669-9681. [CrossRef] [PubMed]

47. Renier, S.; Hébraud, M.; Desvaux, M. Molecular biology of surface colonization by Listeria monocytogenes: An additional facet of an opportunistic Gram-positive foodborne pathogen. Environ. Microbiol. 2011, 13, 835-850. [CrossRef] [PubMed]

48. Chavant, P.; Martinie, B.; Meylheuc, T.; Bellon-Fontaine, M.N.; Hebraud, M. Listeria monocytogenes LO28: Surface physicochemical properties and ability to form biofilms at different temperatures and growth phases. Appl. Environ. Microbiol. 2002, 68, 728-737. [CrossRef] [PubMed]

49. Marsh, E.J.; Luo, H.; Wang, H. A three-tiered approach to differentiate Listeria monocytogenes biofilm-forming abilities. FEMS Microbiol. Lett. 2003, 228, 203-210. [CrossRef]

50. Rieu, A.; Briandet, R.; Habimana, O.; Garmyn, D.; Guzzo, J.; Piveteau, P. Listeria monocytogenes EGD-e biofilms: No mushrooms but a network of knitted chains. Appl. Environ. Microbiol. 2008, 74, 4491-4497. [CrossRef] [PubMed]

51. Guilbaud, M.; Piveteau, P.; Desvaux, M.; Brisse, S.; Briandet, R. Exploring the diversity of Listeria monocytogenes biofilm architecture by high-throughput confocal laser scanning microscopy and the predominance of the honeycomb-like morphotype. Appl. Environ. Microbiol. 2015, 81, 1804-1810. [CrossRef] [PubMed]

52. Bridier, A.; Dubois-Brissonnet, F.; Boubetra, A.; Thomas, V.; Briandet, R. The biofilm architecture of sixty opportunistic pathogens deciphered using a high throughput CLSM method. J. Microbiol. Methods 2010, 82, 64-70. [CrossRef] [PubMed]

53. Hancock, L.E.; Perego, M. The enterococcus faecalis fsr two-component system controls biofilm development through production of gelatinase. J. Bacteriol. 2004, 186, 5629-5639. [CrossRef] [PubMed]

54. Zameer, F.; Gopal, S.; Krohne, G.; Kreft, J. Development of a biofilm model for Listeria monocytogenes EGD-e. World J. Microbiol. Biotechnol. 2010, 26, 1143-1147. [CrossRef]

55. Chen, L.H.; Köseoglu, V.K.; Guvener, Z.T.; Myers-Morales, T.; Reed, J.M.; D'Orazio, S.E.; Miller, K.W.; Gomelsky, M. Cyclic di-GMP-dependent signaling pathways in the pathogenic firmicute Listeria monocytogenes. PLoS Pathog. 2014, 10. [CrossRef] [PubMed]

56. Tiensuu, T.; Andersson, C.; Rydén, P.; Johansson, J. Cycles of light and dark co-ordinate reversible colony differentiation in Listeria monocytogenes. Mol. Microbiol. 2013, 87, 909-924. [CrossRef] [PubMed]

57. Hefford, M.A.; D'Aoust, S.; Cyr, T.D.; Austin, J.W.; Sanders, G.; Kheradpir, E.; Kalmokoff, M.L. Proteomic and microscopic analysis of biofilms formed by Listeria monocytogenes 568. Can. J. Microbiol. 2005, 51, 197-208. [CrossRef] [PubMed]

58. Cywes-Bentley, C.; Skurnik, D.; Zaidi, T.; Roux, D.; DeOliveira, R.B.; Garrett, W.S.; Lu, X.; O'Malley, J.; Kinzel, K.; Zaidi, T.; et al. Antibody to a conserved antigenic target is protective against diverse prokaryotic and eukaryotic pathogens. Proc. Natl. Acad. Sci. USA 2013, 110, E2209-E2218. [CrossRef] [PubMed]

59. Combrouse, T.; Sadovskaya, I.; Faille, C.; Kol, O.; Guérardel, Y.; Midelet-Bourdin, G. Quantification of the extracellular matrix of the Listeria monocytogenes biofilms of different phylogenic lineages with optimization of culture conditions. J. Appl. Microbiol. 2013, 114, 1120-1131. [CrossRef] [PubMed]

60. Brauge, T.; Sadovskaya, I.; Faille, C.; Benezech, T.; Maes, E.; Guerardel, Y.; Midelet-Bourdin, G. Teichoic acid is the major polysaccharide present in the Listeria monocytogenes biofilm matrix. FEMS Microbiol. Lett. 2016, 363. [CrossRef] [PubMed]

61. Koseoglu, V.K.; Heiss, C.; Azadi, P.; Topchiy, E.; Guvener, Z.T.; Lehmann, T.E.; Miller, K.W.; Gomelsky, M. Listeria monocytogenes exopolysaccharide: Origin, structure, biosynthetic machinery and c-di-GMP-dependent regulation. Mol. Microbiol. 2015, 96, 728-743. [CrossRef] [PubMed]

62. Zetzmann, M.; Okshevsky, M.; Endres, J.; Sedlag, A.; Caccia, N.; Auchter, M.; Waidmann, M.S.; Desvaux, M.; Meyer, R.L.; Riedel, C.U. Dnase-sensitive and -resistant modes of biofilm formation by Listeria monocytogenes. Front. Microbiol. 2015, 6, 1428. [CrossRef] [PubMed]

63. Wingender, J.; Strathmann, M.; Rode, A.; Leis, A.; Flemming, H.C. Isolation and biochemical characterization of extracellular polymeric substances from Pseudomonas aeruginosa. Method Enzymol. 2001, 336, 302-314. 
64. Frolund, B.; Palmgren, R.; Keiding, K.; Nielsen, P.H. Extraction of extracellular polymers from activated sludge using a cation exchange resin. Water Res. 1996, 30, 1749-1758. [CrossRef]

65. Evans, L.R.; Linker, A. Production and characterization of the slime polysaccharide of Pseudomonas aeruginosa. J. Bacteriol. 1973, 116, 915-924. [PubMed]

66. Sadovskaya, I.; Vinogradov, E.; Flahaut, S.; Kogan, G.; Jabbouri, S. Extracellular carbohydrate-containing polymers of a model biofilm-producing strain, Staphylococcus epidermidis rp62a. Infect. Immun. 2005, 73, 3007-3017. [CrossRef] [PubMed]

67. Alonso, A.N.; Perry, K.J.; Regeimbal, J.M.; Regan, P.M.; Higgins, D.E. Identification of Listeria monocytogenes determinants required for biofilm formation. PLoS ONE 2014, 9, e113696. [CrossRef] [PubMed]

68. Longhi, C.; Scoarughi, G.L.; Poggiali, F.; Cellini, A.; Carpentieri, A.; Seganti, L.; Pucci, P.; Amoresano, A.; Cocconcelli, P.S.; Artini, M.; et al. Protease treatment affects both invasion ability and biofilm formation in Listeria monocytogenes. Microb. Pathog. 2008, 45, 45-52. [CrossRef] [PubMed]

69. Nguyen, U.T.; Burrows, L.L. Dnase i and proteinase k impair Listeria monocytogenes biofilm formation and induce dispersal of pre-existing biofilms. Int. J. Food Microbiol. 2014, 187, 26-32. [CrossRef] [PubMed]

70. Franciosa, G.; Maugliani, A.; Scalfaro, C.; Floridi, F.; Aureli, P. Expression of internalin a and biofilm formation among Listeria monocytogenes clinical isolates. Int. J. Immunopathol. Pharmacol. 2009, 22, 183-193. [PubMed]

71. Jordan, S.J.; Perni, S.; Glenn, S.; Fernandes, I.; Barbosa, M.; Sol, M.; Tenreiro, R.P.; Chambel, L.; Barata, B.; Zilhao, I.; et al. Listeria monocytogenes biofilm-associated protein (BapL) may contribute to surface attachment of L. monocytogenes but is absent from many field isolates. Appl. Environ. Microbiol. 2008, 74, 5451-5456. [CrossRef] [PubMed]

72. Lemon, K.P.; Higgins, D.E.; Kolter, R. Flagellar motility is critical for Listeria monocytogenes biofilm formation. J. Bacteriol. 2007, 189, 4418-4424. [CrossRef] [PubMed]

73. Lourenco, A.; de Las Heras, A.; Scortti, M.; Vazquez-Boland, J.; Frank, J.F.; Brito, L. Comparison of Listeria monocytogenes exoproteomes from biofilm and planktonic state: Lmo2504, a protein associated with biofilms. Appl. Environ. Microbiol. 2013, 79, 6075-6082. [CrossRef] [PubMed]

74. Harmsen, M.; Lappann, M.; Knochel, S.; Molin, S. The role of extra-cellular DNA during biofilm formation of Listeria monocytogenes. Appl. Environ. Microbiol. 2010, 76, 3625-3636. [CrossRef] [PubMed]

75. Okshevsky, M.; Meyer, R.L. The role of extracellular DNA in the establishment, maintenance and perpetuation of bacterial biofilms. Crit. Rev. Microbiol. 2015, 41, 341-352. [CrossRef] [PubMed]

76. Sadovskaya, I.; Vinogradov, E.; Li, J.; Jabbouri, S. Structural elucidation of the extracellular and cell-wall teichoic acids of Staphylococcus epidermidis RP62A, a reference biofilm-positive strain. Carbohydr. Res. 2004, 339, 1467-1473. [CrossRef] [PubMed]

77. Whitney, J.C.; Howell, P.L. Synthase-dependent exopolysaccharide secretion in gram-negative bacteria. TIM 2013, 21, 63-72. [CrossRef] [PubMed]

78. Merighi, M.; Lee, V.T.; Hyodo, M.; Hayakawa, Y.; Lory, S. The second messenger bis-( $\left.3^{\prime}-5^{\prime}\right)$-cyclic-GMP and its PilZ domain-containing receptor Alg44 are required for alginate biosynthesis in Pseudomonas aeruginosa. Mol. Microbiol. 2007, 65, 876-895. [CrossRef] [PubMed]

79. Lee, V.T.; Matewish, J.M.; Kessler, J.L.; Hyodo, M.; Hayakawa, Y.; Lory, S. A cyclic-di-GMP receptor required for bacterial exopolysaccharide production. Mol. Microbiol. 2007, 65, 1474-1484. [CrossRef] [PubMed]

80. Ross, P.; Weinhouse, H.; Aloni, Y. Regulation of cellulose synthesis in Acetobacter xylinum by cyclic diguanylic acid. Nature 1987, 325, 279-281. [CrossRef] [PubMed]

81. Ryjenkov, D.A.; Simm, R.; Römling, U.; Gomelsky, M. The pilz domain is a receptor for the second messenger c-di-GMP: The PilZ domain protein ycgr controls motility in enterobacteria. J. Biol. Chem. 2006, 281, 30310-30314. [CrossRef] [PubMed]

82. Morgan, J.L.W.; Strumillo, J.; Zimmer, J. Crystallographic snapshot of cellulose synthesis and membrane translocation. Nature 2013, 493, 181-186. [CrossRef] [PubMed]

83. Romling, U.; Galperin, M.Y.; Gomelsky, M. Cyclic di-GMP: The first 25 years of a universal bacterial second messenger. Microbiol. Mol. Biol. Rev. 2013, 77, 1-52. [CrossRef] [PubMed]

84. Shanahan, C.A.; Strobel, S.A. The bacterial second messenger c-di-GMP: Probing interactions with protein and RNA binding partners using cyclic dinucleotide analogs. Org. Biomol. Chem. 2012, 10, 9113-9129. [CrossRef] [PubMed] 
85. Smoot, L.M.; Pierson, M.D. Influence of environmental stress on the kinetics and strength of attachment of Listeria monocytogenes Scott A to Buna-N rubber and stainless steel. J. Food Prot. 1998, 61, 1286-1292. [PubMed]

86. Desvaux, M.; Dumas, E.; Chafsey, I.; Chambon, C.; Hébraud, M. Comprehensive appraisal of the extracellular proteins from a monoderm bacterium: Theoretical and empirical exoproteomes of Listeria monocytogenes egd-e by secretomics. J. Proteome Res. 2010, 9, 5076-5092. [CrossRef] [PubMed]

87. Bierne, H.; Cossart, P. Listeria monocytogenes surface proteins: From genome predictions to function. Microbiol. Mol. Biol. Rev. 2007, 71, 377-397. [CrossRef] [PubMed]

88. Lasa, I. Towards the identification of the common features of bacterial biofilm development. Int. Microbiol. 2006, 9, 21-28. [PubMed]

89. Cucarella, C.; Solano, C.; Valle, J.; Amorena, B.; Lasa, Í.; Penadés, J.R. Bap, a Staphylococcus aureus surface protein involved in biofilm formation. J. Bacteriol. 2001, 183, 2888-2896. [CrossRef] [PubMed]

90. Toledo-Arana, A.; Valle, J.; Solano, C.; Arrizubieta, M.J.; Cucarella, C.; Lamata, M.; Amorena, B.; Leiva, J.; Penades, J.R.; Lasa, I. The enterococcal surface protein, Esp, is involved in Enterococcus faecalis biofilm formation. Appl. Environ. Microbiol. 2001, 67, 4538-4545. [CrossRef] [PubMed]

91. Latasa, C.; Roux, A.; Toledo-Arana, A.; Ghigo, J.M.; Gamazo, C.; Penades, J.R.; Lasa, I. Bapa, a large secreted protein required for biofilm formation and host colonization of Salmonella enterica serovar enteritidis. Mol. Microbiol. 2005, 58, 1322-1339. [CrossRef] [PubMed]

92. Hinsa, S.M.; Espinosa-Urgel, M.; Ramos, J.L.; O'Toole, G.A. Transition from reversible to irreversible attachment during biofilm formation by Pseudomonas fluorescens WCS365 requires an ABC transporter and a large secreted protein. Mol. Microbiol. 2003, 49, 905-918. [CrossRef] [PubMed]

93. Todhanakasem, T.; Young, G.M. Loss of flagellum-based motility by Listeria monocytogenes results in formation of hyperbiofilms. J. Bacteriol. 2008, 190, 6030-6034. [CrossRef] [PubMed]

94. Peel, M.; Donachie, W.; Shaw, A. Temperature-dependent expression of flagella of Listeria monocytogenes studied by electron microscopy, SDS-PAGE and western blotting. J. Gen. Microbiol. 1988, 134, 2171-2178. [PubMed]

95. Hall-Stoodley, L.; Nistico, L.; Sambanthamoorthy, K.; Dice, B.; Nguyen, D.; Mershon, W.J.; Johnson, C.; Ze Hu, F.; Stoodley, P.; Ehrlich, G.D.; et al. Characterization of biofilm matrix, degradation by dnase treatment and evidence of capsule downregulation in Streptococcus pneumoniae clinical isolates. BMC Microbiol. 2008, 8. [CrossRef] [PubMed]

96. Izano, E.A.; Amarante, M.A.; Kher, W.B.; Kaplan, J.B. Differential roles of poly-N-acetylglucosamine surface polysaccharide and extracellular DNA in Staphylococcus aureus and Staphylococcus epidermidis biofilms. Appl. Environ. Microbiol. 2008, 74, 470-476. [CrossRef] [PubMed]

97. Mann, E.E.; Rice, K.C.; Boles, B.R.; Endres, J.L.; Ranjit, D.; Chandramohan, L.; Tsang, L.H.; Smeltzer, M.S.; Horswill, A.R.; Bayles, K.W. Modulation of eDNA release and degradation affects Staphylococcus aureus biofilm maturation. PLoS ONE 2009, 4, e5822. [CrossRef] [PubMed]

98. Seper, A.; Fengler, V.H.I.; Roier, S.; Wolinski, H.; Kohlwein, S.D.; Bishop, A.L.; Camilli, A.; Reidl, J.; Schild, S. Extracellular nucleases and extracellular DNA play important roles in Vibrio cholerae biofilm formation. Mol. Microbiol. 2011, 82, 1015-1037. [CrossRef] [PubMed]

99. Liao, S.; Klein, M.I.; Heim, K.P.; Fan, Y.; Bitoun, J.P.; Ahn, S.J.; Burne, R.A.; Koo, H.; Brady, L.J.; Wen, Z.T. Streptococcus mutans extracellular DNA is upregulated during growth in biofilms, actively released via membrane vesicles, and influenced by components of the protein secretion machinery. J. Bacteriol. 2014, 196, 2355-2366. [CrossRef] [PubMed]

100. Kadam, S.R.; den Besten, H.M.W.; van der Veen, S.; Zwietering, M.H.; Moezelaar, R.; Abee, T. Diversity assessment of Listeria monocytogenes biofilm formation: Impact of growth condition, serotype and strain origin. Int. J. Food Microbiol. 2013, 165, 259-264. [CrossRef] [PubMed]

101. Flemming, H.C.; Neu, T.R.; Wozniak, D.J. The EPS matrix: The “house of biofilm cells”. J. Bacteriol. 2007, 189, 7945-7947. [CrossRef] [PubMed]

(C) 2016 by the authors; licensee MDPI, Basel, Switzerland. This article is an open access article distributed under the terms and conditions of the Creative Commons Attribution (CC-BY) license (http://creativecommons.org/licenses/by/4.0/). 